\title{
SILK USE AND SPIDERLING BEHAVIOR IN THE TARANTULA BRACHYPELMA VAGANS (ARANEAE: THERAPHOSIDAE)
}

\author{
ARIANe DOR \& YANn HÉNAUT ${ }^{1}$ \\ El colegio de la Frontera Sur (Ecosur)-Unidad Chetumal. Avenida Centenario, km 5.5, C.P. 77014, \\ Chetumal, Quintana Roo, México. Ariane Dor<ariane.dor@gmail.com> \\ ${ }^{1}$ Corresponding author: Yann Hénaut <yhenaut@ecosur.mx>
}

Dor, A. \& Y. Hénaut. 2012. Silk use and spiderling behavior in the tarantula Brachypelma vagans (Araneae: Theraphosidae). Acta Zoológica Mexicana (n. s.), 28(1): 1-12.

ABSTRACT. Brachypelma vagas belongs to a genus of tarantulas protected against illegal trading. Its distribution range is in Mesoamerica. The spiderlings remain together in the maternal burrow after hatching and after several weeks, they disperse forming a column of about hundred individuals leading away from the burrow. In several spider species, during the gregarious phase and dispersion, spiderlings do not show aggressive behavior toward siblings. Silk is an important element in dispersion. However, knowledge of the first stage of $B$. vagans life is scarce. In the present study, therefore, we describe the natural history of the first stage of life of this species, with particular attention to the development, silk production, interactions between sibling and dispersion. Two egg sacs were collected in the field and maintained in laboratory conditions, without the mother. After hatching, we counted 200 individuals per egg sac; they are cream colored and 2-3 mm long. The first molt occurred at emergence, and the second, five or six days after hatching. After that, a black point appeared on the dorsal part of the abdomen of each spiderling. Production of silk by the spiderlings began from hatching. Dispersion occurred in one group of siblings on the $8^{\text {th }}$ day after emergence, with the production of a thread of silk stretching for at least one meter out of the box. The silk thread produced by the spiderlings during dispersal, could act as a physical guide to indicate the route, or as the support of chemical signs for the orientation of the spiderlings. The absence of silk thread reported in field observations of dispersal could be explained by the fact that it is difficult to see, by lack of production or by production that is environment-dependent. In the group where dispersion was not permitted, no aggressive behavior was observed between siblings; however, a drastic diminution of the individual number occurred in the course of the two-month observation. Mortality could be explained by diseases, unsuitable environmental conditions related to the mother's absence or not. On the other hand, the remaining spiderlings showed an enlargement of their abdomen in spite of refusal to eat the diary food proposed. It is likely they ate spiderling cadavers or silk. This work offers new knowledge about the first life stage in tarantulas and could be used as a basis for more detailed studies on spiderlings of the tarantula group.

Key words: Spiderlings, Brachypelma vagans, silk, aggressiveness, sibling.

Recibido: 25/06/2009; aceptado: 01/11/2011. 
Dor, A. \& Y. Hénaut. 2012. Uso de la seda y comportamiento de las crías en la tarántula Brachypelma vagans (Araneae: Theraphosidae). Acta Zoológica Mexicana (n. s.), 28(1): 1-12.

RESUMEN. Brachypelma vagans pertenece a un género de tarántula protegido contra el comercio ilegal. Se distribuye en Mesoamérica. Sus crías permanecen juntas en la madriguera de su madre después de la eclosión. Varias semanas después, se dispersan formando una columna de un centenar de individuos. En varias especies de arañas, durante su fase gregaria y la dispersión, las crías de arañas no presentan agresividad hacia sus hermanos y la seda es un elemento importante en la dispersión. Sin embargo, existe poca información acerca de los primeros momentos de vida de $B$. vagans. Por lo tanto, en este trabajo proponemos describir la historia natural de arañas recién nacidas de esta especie, con una atención particular en su desarrollo, la producción de seda, el comportamiento entre las crías hermanas y su dispersión. Dos sacos de huevos fueron colectados en el campo y mantenidos en condiciones de laboratorio, sin su madre. Después de la emergencia se contaron unos 200 individuos por ovisaco, de color crema y de 2-3 mm de largo. La primera muda ocurrió al momento de la emergencia de las crías del ovisaco, y la segunda a los días cinco o seis después de la emergencia. A partir de este momento, apareció un punto negro en la parte dorsal del abdomen de cada cría. La producción de seda por las crías de ambos ovisacos empezó desde la eclosión. La dispersión ocurrió el octavo día después de la emergencia de un grupo de crías hermanas, con la producción de un hilo de seda de al menos un metro de largo. La producción de tal hilo de seda por las crías durante la dispersión, puede actuar como una guía física indicando el camino, o como el soporte de una señal química para la orientación de las crías. La ausencia de hilo de seda durante la dispersión en el campo puede ser explicada por la imposibilidad de detectarlo por los observadores, la ausencia de producción, o una producción dependiente del entorno ambiental. En la camada a la que se impidió la dispersión, no se observó conducta agresiva entre las crías; sin embargo, se observó una disminución drástica del número de individuos en el curso de los dos meses de observación. La mortalidad podría ser causada por enfermedades, condiciones ambientales no apropiadas ligadas o no a la ausencia de la madre. Por otra parte, las arañas que permanecieron vivas vieron su abdomen alargarse a pesar de negarse a comer la comida propuesta diariamente. Es posible que comieran los cadáveres de las crías o la seda para sustentar sus necesidades. Este estudio ofrece nuevos conocimientos acerca de los primeros momentos de vida de tarántulas y puede servir de base para estudios más detallados sobre las crías de este grupo de arañas.

Palabras clave: Crías, Brachypelma vagans, seda, agresividad, crías hermanas.

\section{INTRODUCTION}

Brachypelma vagans (Ausserer, 1875) (Mygalomorphae: Theraphosidae), like all species of Brachypelma, is considered to be an endangered species of tarantula (appendix II of CITES), given their high value in the pet trade and destruction of their natural habitat (Baerg 1958; Locht et al. 1999). Brachypelma tarantulas are officially protected but few studies have been performed to increase our knowledge of their ecology (Yáñez \& Floater 2000; Machkour M'Rabet et al. 2005, 2007) and behavior (Locht et al. 1999; Reichling 2000; Dor et al. 2008, 2011; Dor \& Hénaut in press). Brachypelma vagans is reported from Mexico, Belize, El Salvador, Guatemala, Honduras and Costa Rica (Valerio 1980), but it has also been recorded in the wild in Florida (Edwards \& Hibbard 1999), most probably after being released. In Mexico, $B$. vagans is distributed throughout the south of the country including Chiapas, the peninsula of Yucatán, Tabasco and Veracruz (Yáñez et al. 1999). Although B. vagans 
is sold as a pet, its value is the lowest among the various Mexican tarantulas owing to its widespread distribution and lack of rarity.

Most observations concerning B. vagans have been performed in captivity (Baxter 1993). Recently, observations were made in the Yucatán peninsula, where a high density of tarantula burrows is associated with traditional human communities. Moderate levels of human disturbance create favorable microhabitats for the installation of $B$. vagans colonies (Machkour-M'Rabet et al. 2005). Indeed, traditional human communities are often concurrent with deep clay soil, and absence of roots, which is favorable for burrow excavation (Machkour-M'Rabet et al. 2007). Machkour-M'Rabet et al. (2005) also showed that different life stages occupied different sites: in one village, females and the youngest juveniles (called spiderlings) occupied backyards, whereas pre-adults occupied the football field. Only few males were observed and it is probable that they move between populations of females: a strategy which prevents inbreeding (Machkour-M'Rabet et al. 2009). This association between tarantulas and the human community is not only ecological but also cultural with the use of those spiders in traditional medicine (Machkour-M'Rabet et al. 2011).

In February, B. vagans females make a large silken egg sac $4-5 \mathrm{~cm}$ in diameter, containing around 500 eggs. Females take care of it until the spiderlings hatch in May-June. The spiderlings, which have a body length of about 2-3 $\mathrm{mm}$, stay in the maternal burrow for several weeks. Little is known of this gregarious stage in this species, although spiderlings have been observed moving around the entrance of the maternal burrow, in where their mother is hunting in a sit-and-wait position. They often climb over each other but avoid contact with the mother. During daytime, the spiderlings were known to remain active and visible at the entrance of the burrow for up to one hour after the female had retreated. They were able to move easily through the web covering laid by the female over the burrow entrance (Shillington $\&$ McEwen 2006). Authors hypothesized that the silk network around the burrow provides an important chemotactic cue for orientation (Minch 1978) and juveniles probably remain in contact with this network at all times. After this gregarious period, the spiderlings disperse in the form of columns of about 100 siblings walking away from the mother's burrow (Reichling 2000, 2003; Shillington \& McEwen 2006). Shillington \& McEwen (2006) observed that during the night of May $24^{\text {th }} 2003$, spiderlings left the maternal burrow in three lines. Then at random intervals, one individual left the column and headed in a different direction, causing successive forks in the column. The maximum observed distance of dispersal was $9 \mathrm{~m}$ from the maternal burrow. Dispersal is observed in several spider species, including several species of mygalomorphae, all using silk for ballooning (Coyle 1983) or orientation (Jeanson et al. 2004). Previous reports on B. vagans mention that the spiderlings walk in line like ants (Reichling 2000), but no work has recorded the use of silk during dispersal. 
During their gregarious and dispersal phases the spiderlings do not show any aggressive behavior toward each other, as many spiders do (Gundermann et al. 1986; Jeanson et al. 2004). Once established in a burrow, however, B. vagans pre-adults and adults are highly aggressive towards conspecifics with reported cases of cannibalism (Hénaut \& Machkour-M'Rabet 2005; Dor et al. 2008). Reichling (2003) hypothesized that spiderlings learn to recognize kin during their life in the maternal burrow, but no supporting evidence was provided. If this kind of learning does exist we may expect that spiderlings start to learn when they are all together in the maternal burrow, and would not be aggressive towards siblings during this time. Moreover, kin recognition learning could occur very quickly, as observed in social spiders (Evans 1999) and other organisms (Hepper 1991, Robinson \& Smotherman 1991).

Information about common Brachypelma vagans spiderling behavior is particularly valuable in the context of ontogeny and life history of these spiders considering the lack of knowledge about the genus Brachypelma. In this study we describe the natural history of the first moments of life in tarantula spiderlings, with a particular focus on their development, silk production, dispersion, and with attention to their behavior during a forced two-month gregarious life.

\section{MATERIALS AND METHODS}

Field observations and egg sac collection. On March 23, 2007, two B. vagans females were collected in the villages of "Zoh-Laguna" (N 18 35' 34' and W 89 $24^{\circ}$ '

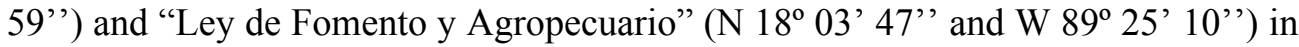
the state of Campeche, Mexico. Both spiders were encountered underneath a stone at the edge of a dirt track near the two villages. They were carrying a spherical white egg sac about $4 \mathrm{~cm}$ in diameter. On May $2^{\text {nd }} 2005$, in the neighboring village "Once de Mayo" ( $\mathrm{N} 18^{\circ} 05^{\prime} 28^{\prime \prime}$ ' and $\mathrm{W} 89^{\circ} 27^{\prime}$ 43' '), we reported spiderling dispersal on a dirt track located to the north of a football field. The football field had a colony of adult and preadult $B$. vagans (Machkour-M'rabet et al. 2005, 2007; Dor \& Weissenberger 2005) and has a root-free clay soil.

Laboratory rearing. In the laboratory (ECOSUR Chetumal), the egg sacs of the collected females were kept separately in plastic boxes (base $20 \times 13 \mathrm{~cm}$, height $13 \mathrm{~cm}$; see Fig. 3), with a $4 \mathrm{~cm}$ layer of clay soil collected at the site where we had made the natural observations, and pieces of branch and stones. This semi-natural environment was maintained at 24 to $28^{\circ} \mathrm{C}$ with a natural 12-hr:12-hr light:dark photoperiod. Water was regularly sprayed on the ground to maintain a relative humidity of $60-80$ $\%$; a net cover allowed aeration of the box and prevented the escape of spiderlings. Both boxes were put on a shelf $1.6 \mathrm{~m}$ above the ground, and kept free of predators, particularly ants, with a regular cleaning and traps to avoid insects climbing. In laboratory rearing conditions, female $B$. vagans provided maternal care by turning the 
egg sac so the eggs on the bottom were at the top for a while, preventing adherence between the eggs (Baxter 1993). We did not leave the females with their eggs to avoid deposition of silk by the female, and prevent cannibalism of the offspring, which can sometimes occur at emergence. In order to promote normal development of the spider larvae, the egg sacs were gently and periodically turned manually in the boxes.

Immediately after emergence from the cocoon, small pieces of living Zophobas morio (Coleoptera, Tenebrionidae) larvae were fed to the spiderlings, which drank the larval fluids. For each group, two Zophobas morio larvae were cut in two pieces at the intersection of segments and a piece placed at each corner in of the spiderling box, on the ground in order to make larval fluids available to all spiderlings. We daily removed the remains of the Zophobas and put new pieces in their places. Observations were made every day from 10:00 to 11:00 a.m.

Spiderling development, silk production and behavior. Dates of hatching of the egg in the two sacs were recorded, as was the date of each molting. During the first two months of spiderling life, the numbers of spiderlings were estimated daily by direct counting of spiderlings in four rectangles of $13 \times 5 \mathrm{~cm}$ along the base of the box; body lengths of five spiderlings (anterior extremity of the cephalothorax to the hindmost part of the abdomen) were measured with a ruler, color changes were recorded, and silk production was noted, recording increases in the amount of silk in the box, and describing the patterns of silk laid down by the spiderlings. We decided, during the first week before dispersion, not to separate spiderling individuals so as not to perturb the whole group and silk structure. Interactive behavior between siblings was observed through the occurrences of aggressiveness between individuals, grouping of individuals, or individuals remaining separate.

\section{RESULTS}

Field observations. On May $2^{\text {nd }} 2005$ at 4:35 p.m., a sunny day with dispersed cloud, a temperature of about $24^{\circ} \mathrm{C}$ and air humidity of about $60 \%$, we observed a column about 1.8 meters long of 200 or so B. vagans spiderlings crossing a dust track by the football field in "Once de Mayo" village (Fig. 1). This number of spiderlings is larger than previously reported. Spiderlings were $4-5 \mathrm{~mm}$ in body length and appeared to be coming from the football field to the south. The column of spiders moved about 3 meters in 2 minutes and disappeared in the grass and rocks by the north side of the road. North of the track is the yard of a house, with shrubs and trees. The clay soil there contained roots, and we did not find any tarantulas there. We did not observe the presence of silk in this "ant line" type dispersal. However, in natural conditions such as these, it is difficult to distinguish the presence of fine spiderling silk on the ground. 


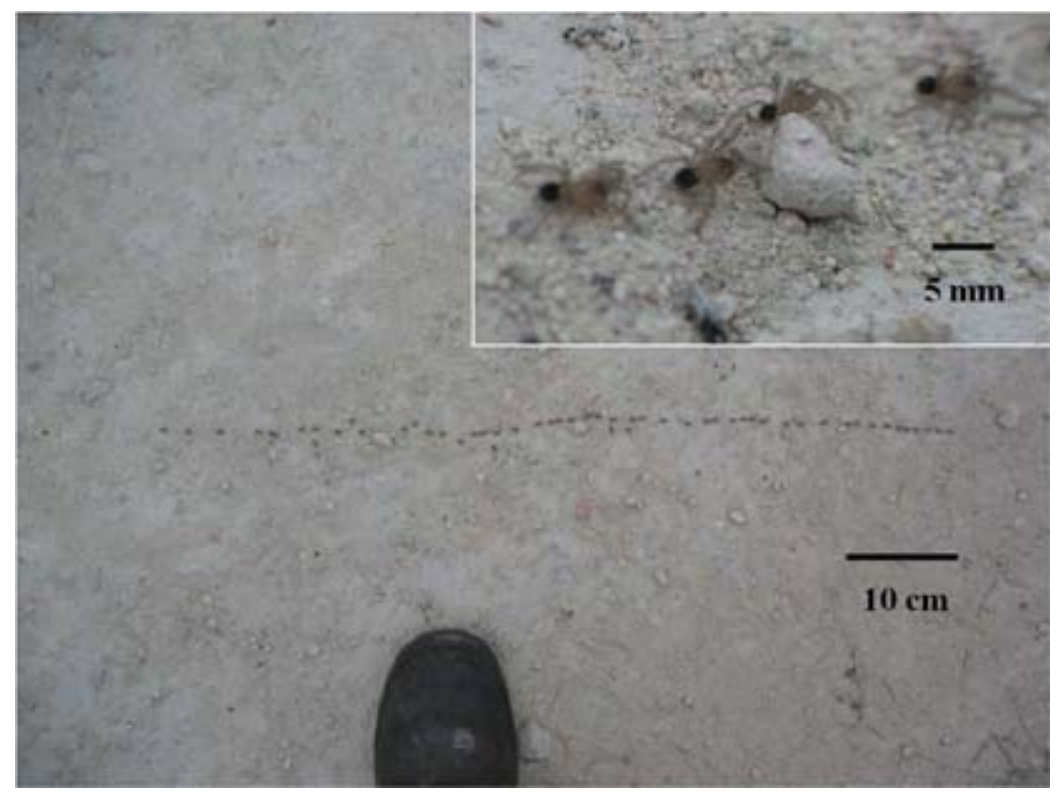

Figure 1. A column of about 200 B. vagans spiderlings observed on the road by the football field in Once de Mayo village, State of Campeche, Mexico. May 2nd 2005. Photo: Ariane Dor.

Spiderling development. The spiderlings of the two egg sacs hatched at different dates (Table 1), around 200 spiderlings hatched from both egg sacs 1 and 2. For egg sac 1 , we observed abundant exuvia in the silk net on May $14^{\text {th }}$, indicating the occurrence of the spiderlings' first molt. For egg sac 2, the first molt occurred on hatching, since on the morning of hatching; the open egg sac had a heap of exuviae at the entrance. The spiderlings' body length was 2-3 mm; they were then cream colored. The second molt occurred when the spiderlings were about 4-5 $\mathrm{mm}$ in body length and changed

Table 1. Chronology of hatching, molting and dispersal of spiderlings of egg sacs 1 and 2.

\begin{tabular}{|c|c|c|}
\hline & Egg sac 1 & Egg sac 2 \\
\hline Site & Zoh-Laguna & Ley de Fomento y Agropecuario \\
\hline Female collected & $\operatorname{March} 23^{\text {rd }}$ & March $23^{\text {rd }}$ \\
\hline Hatching & Night* previous to May $13^{\text {th }}$ & Night* previous to May $17^{\text {th }}$ \\
\hline First molt & May $14^{\text {th }}$ & Night* previous to May $17^{\text {th }}$ \\
\hline Second molt & May $17^{\text {th }}$ & May $23^{\text {rd }}$ \\
\hline Dispersal & Night* previous to May $20^{\text {th }}$ & - \\
\hline
\end{tabular}

* Between 8:00 p.m. and 8:00 a.m. 
their color pattern to have a black spot on the dorsal abdomen (Fig. 2). No more molting was observed. Spiderlings of both egg sacs were active during both day and night, but fled direct light. As the Zophobas morio segments remained intact, it is likely that the spiderlings did not consume the larval fluids.

Silk production. In the absence of the mother, the silk observed as soon as the spiderlings hatched was clearly produced by them. In box 1, silk production was observed for eight days, until dispersal from the box. In box 2, containing the other egg sac and where dispersal was not possible, silk was observed during the first 24 days of the spiderlings' life. In both boxes, the fine silk carpet along the ground was pierced with numerous holes of around $1 \mathrm{~cm}$ in diameter from the third day of life (Fig. 3). The carpet produced in box 1 covered the whole soil surface while that in box 2 covered only

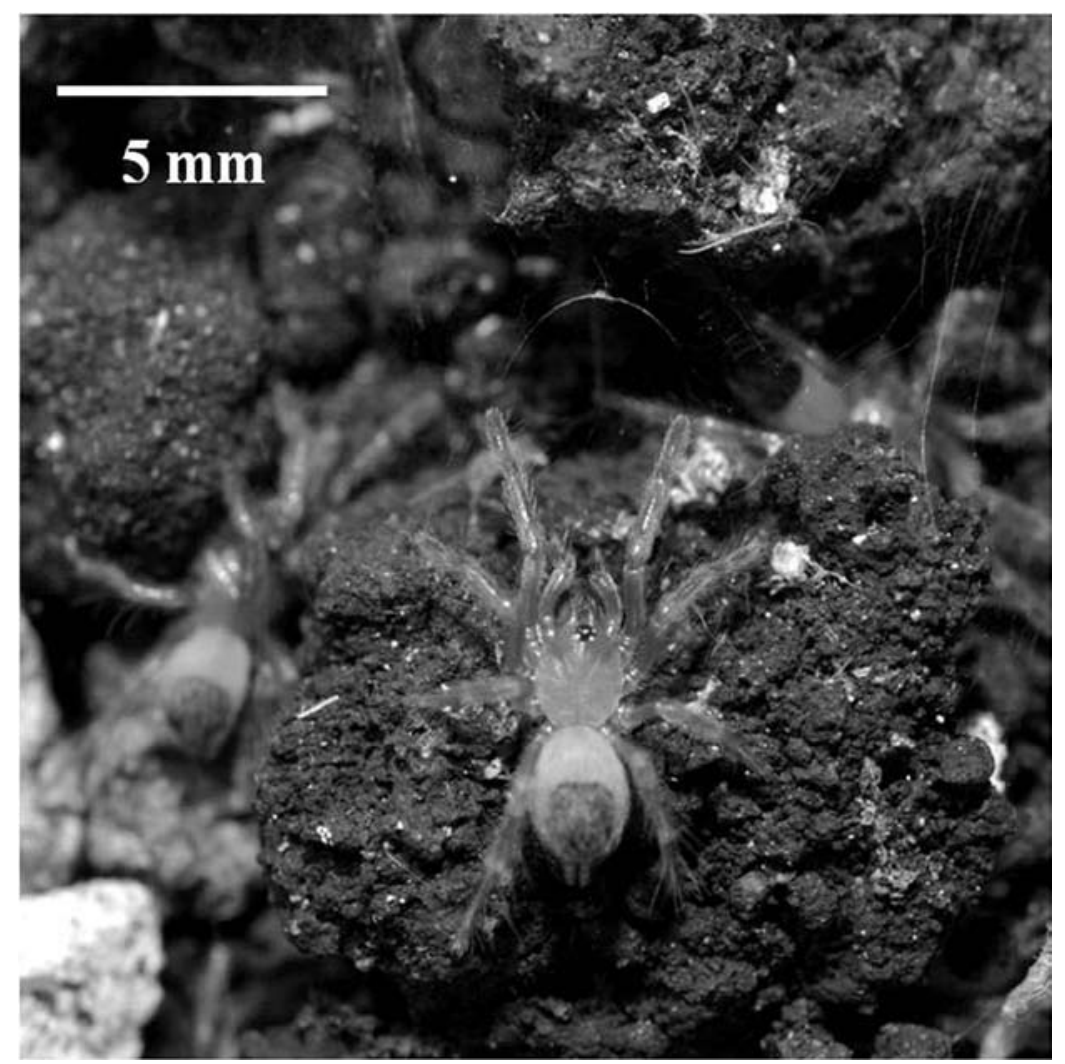

Figure 2. Spiderlings of egg sac 2. They measure $5 \mathrm{~mm}$ in body length, and have a black spot on the dorsal face of the abdomen. May $24^{\text {th }} 2007$ (6 days after hatching). Photo: Humberto Bahena Basave. 


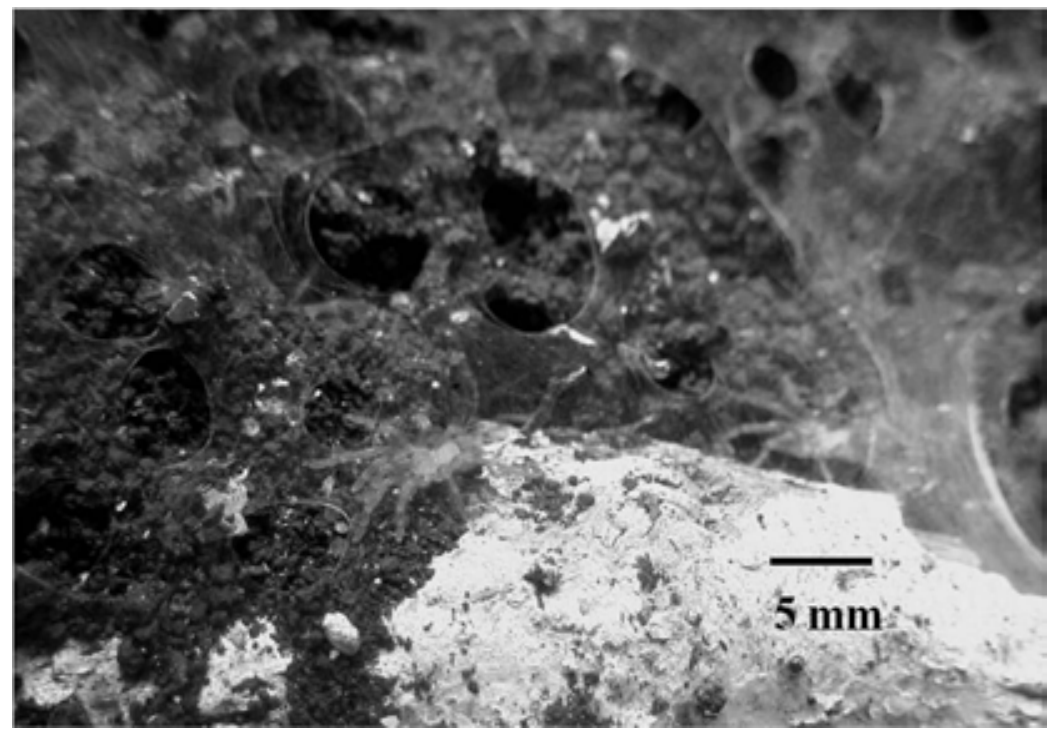

Figure 3. Silk produced by the spiderlings of egg sac 1 . The silk mat has holes about $1 \mathrm{~cm}$ in diameter. May $15^{\text {th }} 2007$ (3 days after hatching). Photo: Ariane Dor.

a third of the soil area, where the heap of exuviae were and around the entries of the small superficial burrows they had excavated in the soil. The holes in the silk carpet seemed to enable the spiderlings to move between the silk surface and the burrows.

On May $29^{\text {th }}$ (12 days after hatching), a network of silk completely covered all the walls of box 2 (Fig. 4). On June $10^{\text {th }}$, the box lid was also covered with silk and tarantulas walked on it. After this date, silk began to disappear.

Dispersion. Despite the fine netting over the box to prevent spiderling escape, during the night before May $20^{\text {th }}$, spiderlings from the first egg sac disappeared from box 1 and left the laboratory. It is probable that the spiderlings discovered a minute opening sufficient to escape from the box. No live spiderlings or cadavers remained in the box, nor was any proof of predator attack found. So, we can assume that this massive exodus was related to spiderling dispersion. Moreover, spiderlings left evidence of their departure with a 1-meter long $0.3 \mathrm{~mm}$ thick of silk threads attached to the box roof and leading to the chipboard shelf where the box was located. The thread followed along the chipboard towards a vertical metal partition with the same thickness as in the board, where it abruptly stopped leaving no trace of any continuation. It was therefore likely that the thread had broken. If it was the production of silk by the spiderlings that had stopped the thread would have become steadily thinner, which we did not observe. 


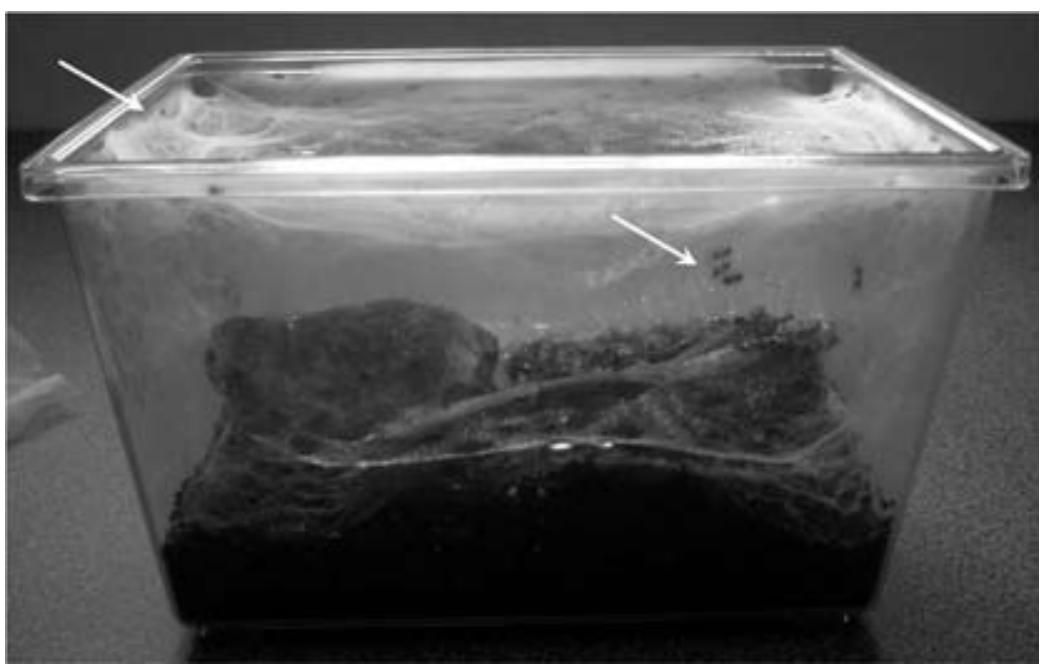

Figure 4. Silk produced by the spiderlings of egg sac 2 . The upper arrow indicates the silk net, and the lower arrow a group of three spiderlings. The plastic box measures $20 \times 13$ at the base and $13 \mathrm{~cm}$ in height. May $29^{\text {th }} 2007$ (12 days after hatching). Photo: Ariane Dor.

Behavior. Siblings from the second egg sac showed apparently pacific behavior towards each other during the two months of observation (until July $20^{\text {th }}$ ). Spiderlings occupied the soil or the walls of the box in groups of 3-8 (Fig. 4) or alone. Observation of groups in superficial small burrows was not possible. It was notable however, that the number of living spiderlings fell to 50 individuals, and that they increased in size from 4-5 $\mathrm{mm}$ after the second molt to $5-10 \mathrm{~mm}$ at the end of the observation. Increased sizes were due to permanent enlargement of the abdomen.

\section{DISCUSSION}

Silk production by spiderlings of the tarantula Brachypelma vagans was recorded from emergence from the egg sac until at least the beginning of dispersal. During the gregarious stage, the silk observed on the ground of the box was produced by spiderlings. It seems that it was deposited on the ground as the spiderlings walked. Production could start since hatching, but this was difficult to distinguish accurately owing to the extreme thinness of the threads. Further direct observations of the silk production of isolated hatchlings may be able to confirm this hypothesis. The presence of a silk carpet could indicate that a particular area is visited more, since individuals went freely into burrow entrances and deposited silk there. Another explanation could be that spiderlings prefer to produce silk in a specific area, since we do not know the function of the silk. This silk production behavior had never been reported in spider- 
lings. The appearance of superficial burrows constructed by spiderlings is also an interesting observation, since it had not been reported in spiderlings either, and could be a possible indicator of emergent territorial behavior in this tarantula.

During dispersal in the field, no silk thread was observed between siblings of the "ant column", whereas a one-meter silk thread was observed in the laboratory dispersal. It was relatively short and stopped abruptly, suggesting that it was broken. Although no silk thread was noted between the dispersing siblings in the field, it may have been so thin that we could not see it. If such a thread exists, spiderlings may produce silk constantly, as they walk, the pattern of the dispersal column allowing the agglutination of many silk threads of the successive spiderlings that pass, depositing silk in the same place. Each spiderling may contribute to the growth of the thread, as observed in the dragline produced by the spider Larinoides cornutus (Araneae: Araneidae) (Jeanson et al. 2004). Shillington and McEwen (2006) observed that not all spiderlings of the same maternal burrow dispersed on the same night. The remaining juveniles started dispersal along the same path as the column of their siblings, which dispersed the previous night. The authors proposed that the spiderlings were able to detect a chemical or tactile cues laid down by their siblings. Thus, individuals may use the silk as a support for their "chemical signals", and orient themselves through odor perception. In B. vagans females, silk is associated to chemical recognition (Dor et al. 2008). Consequently the production of silk by spiderlings before and during dispersal is quite feasibly to chemically mark the path the spiderlings take and permit their dispersal in an "ant line". Spiderlings could produce silk on surfaces where difficult to walk on, facilitating the progress of the following spiderlings. Further detailed laboratory studies should be carried out to enable confirmation or rejection of the hypotheses put forward here.

In each family, siblings aggregated in groups of 4-10 individuals with an absence of aggressive acts observed during the first two months of life, as in several studies in other spider groups (Gundermann et al. 1986; Horel et al. 1996; Jeanson et al. 2004). However, the number of individuals in the second group decreased drastically during the two-month observation. The mortality could be explained by disease, unsuitable rearing conditions, or the mother's absence. The lack of cadavers could be due to the consumption of bodies after death by siblings. Despite the fact that spiderlings did not consume Zophobas larvae fluids, the observation of increasing abdomen length is interesting. Abdomen enlargement is due to storage of fat in the tissues of the abdomen (Foelix 1996). The spiderlings therefore consumed something other than larval fluids. Consumption of siblings, by scavenging, could have enabled abdomen enlargement. Another alternative is silk consumption, since it contains protein and other physiologically important compounds for nutrition (e.g. Tillinghast \& Townley 1987; Miyashita et al. 2004). The progressive disappearance of the silk web after 26 days of life, could indeed indicate its consumption by the spiderlings. The consumption of 
sibling cadavers and silk by spiderlings in $B$. vagans deserves further study. Another unanswered question is why spiderlings disperse in the same direction, instead of dispersing independently of each other. In a previous study we observed that a locally concurrent wolf spider species attacks and eats B. vagans spiderlings (Dor 2008). Their strategy of dispersion may then be considered as a group strategy against predation, as observed in other organisms (Alcock 1997).

In conclusion, our observations of spiderlings of the tarantula Brachypelma vagans showed that the spiderling produces silk during its gregarious stage and at least during the first part of dispersal. We showed the existence of digging behaviour from the first days of life. Absence of aggressiveness between siblings from one egg sac in the first 60 days of life was noted. However, we suspect the consumption of sibling cadavers and spiderlings silk. This work presents new information about first stages of life in a tarantula and opens the way to several possibilities for further study.

ACKNowledgments: We thank the people of the communes Zoh-Laguna, Ley de Fomento y Agropecuario and Once de Mayo for permission to conduct field research. This work was supported by El Colegio de la Frontera Sur - Chetumal. We thank Dominique Lecocq, Heiner Dario Suárez Vázquez, and Nancy Gabriela Sanchéz for their much appreciated practical help and support in the field; Mirna Victoria Yañez Melgoza for reviewing the Spanish abstract, and Peter Winterton for comments on the manuscript.

\section{LITERATURE CITED}

Alcock, J. 1997. Animal Behavior. An evolutionary approach. 6th edition. Sinauer Association, Sunderland, USA.

Baerg, W. J. 1958. The tarantulas. University of Kansas, Lawrence, USA.

Baxter, R. N. 1993. Keeping and breeding tarantulas. Chudleigh Publishing, Ilford, UK.

Coyle, F. A. 1983. Aerial dispersal by mygalomorph spiderlings (Araneae, Mygalomorphae). Journal of Arachnology, 11: 283-286.

Dor, A. 2008. Ecoetología y genética de la tarántula de cadera roja Brachypelma vagans. PhD Thesis. México: ECOSUR-Chetumal.

Dor, A. \& Y. Hénaut. Are cannibalism and tarantula predation, factors of the spatial distribution of the wolf spider Lycosa subfusca (Araneae, Lycosidae)? Ethology, Ecology and Evolution. In press.

Dor, A. \& H. Weissenberger. 2005. Hogna subfusca (Lycosidae) versus Brachypelma vagans (Theraphosidae) en el ejido "11 de Mayo" de Calakmul, Campeche, México - competencia o depredación. Entomología Mexicana, 4: 90-93.

Dor, A., S. Calmé \& Y. Hénaut. 2011. Predatory interactions between Centruroides scorpions and the tarantula Brachypelma vagans. Journal of Arachnology, 39: 201-204.

Dor, A., S. Machkour-M'Rabet, L. Legal, T. Williams \& Y. Hénaut. 2008. Chemically mediated burrow recognition in the Mexican tarantula Brachypelma vagans female. Naturwissenschaften, 95: 11898-1193.

Edwards, G. B. \& K. L. Hibbard. 2003. Mexican redrump tarantula, Brachypelma vagans (Ausserer). UF/IFAS Featured Creatures. EENY-287. http://creatures.ifas.ufl.edu/misc/spiders/M_redrump. htm 
Evans, T. A. 1999. Kin recognition in a social spider. Proceedings of the Royal Society, 266: 287-292.

Foelix, F. R. 1996. Biology of spiders. Oxford University Press, New York, USA.

Gundermann, J.L., A. Horel \& B. Krafft. 1986. Experimental manipulation of social tendencies in the subsocial spider Coelotes terrestris. Insectes Sociaux, 40: 219-229.

Hénaut, Y. \& S. Machkour-M'Rabet. 2005. Canibalismo y cleptobiosis en la tarántula Brachypelma vagans. Entomología Mexicana, 4: 30-32.

Hepper, P. G. 1991. Recognizing kin: Ontogeny and classification, pp.259-288. In: P. G. Hepper (Ed.). Kin recognition. Cambridge University Press, USA.

Horel, A., B. Krafft, \& S. Aron. 1996. Processus de socialisation et préadaptations comportamentales chez les araignées. Bulletin de la Société Zoologique de France, 21: 31-37.

Jeanson, R., J. L. Deneubourg \& G. Theraulaz. 2004. Discrete dragline attachment induces aggregation in spiderlings of a solitary species. Animal Behaviour, 67: 531-537.

Locht, A., M. Yáñez \& I. Vázquez. 1999. Distribution and natural history of Mexican species of Brachypelma and Brachypelmides (Theraphosidae, Theraphosinae) with morphological evidence for their synonymy. Journal of Arachnology, 27: 196-200.

Machkour-M'Rabet, S., Y. Hénaut, A. Dor, G. Pérez-Lachaud, C. Pélissier, C. Gers \& L. Legal. 2009. ISSR (Inter Simle Sequence Repeats) as molecular markers to study genetic diversity in tarantulas (Araneae, Mygalomorphae). Journal of Arachnology, 37: 10-14.

Machkour-M'Rabet S., Y. Hénaut, R. Rojo \& S. Calmé. 2005. A not so natural history of the tarantula Brachypelma vagans: interaction with human activity. Journal of Natural History, 39: 2515-2523.

Machkour-M'Rabet, S., Y. Hénaut, A. Sepúlveda, R. Rojo, S. Calmé \& V. Geissen. 2007. Soil preference and burrow structure of an endangered tarantula, Brachypelma vagans (Mygalomorpheae: Theraphosidae). Journal of Natural History, 41:1025-1033.

Machkour-M'Rabet, S., Y. Hénaut, P. Winterton, R. Rojo. 2011. A case of zootherapy with the tarantula Brachypelma vagans Ausserer, 1875 in traditional medicine of the Chol Mayan ethnic group in Mexico. Journal of Ethnobiology and Ethnomedecine, 7: 12.

Minch, E.W. 1978. Daily activity patterns in the tarantula Aphonopelma chalcodes. Chamberlin. Bulletin of the British Arachnological Society, 4: 231-237

Miyashita, T, Y. Maezono \& A. Shimazaki. 2004. Silk feeding as an alternative foraging tactic in a kleptoparasitic spider under seasonally changing environments. Journal of Zoology, London, 262: 225-229.

Reichling, S. B. 2000. Group dispersal in juvenile Brachypelma vagans (Araneae, Theraphosidae). Journal of Arachnology, 28: 248-250.

Reichling, S. B. 2003. Tarantulas of Belize. Krieger Publishing Company, Malabar, Florida.

Robinson, S. R. \& Smotherman W. S. 1991. Fetal learning: implications for development of kin recognition, pp. 308-334. In: P.G. Hepper (Ed.). Kin recognition. Cambridge University Press, USA.

Shillington, C. \& B. McEwen. 2006. Activity of juvenile tarantulas in and around the maternal burrow. Journal of Arachnology, 34: 261-265.

Tillinghast, E. K. \& M. Townley. 1987. Chemistry, physical properties, and synthesis of Araneidae orb webs, pp. 203-210. In: W. Nentwig (Ed.). Ecophysiology of spiders. Springer-Verlag, Berlin, Germany.

Valerio, C. 1980. Arañas Terafósidas de Costa Rica (Araneae, Theraphosidae). 1. Sericopelma y Brachypelma. Brenesia, 18: 259-288.

Yáñez, M. \& G. Floater. 2000. Spatial distribution and habitat preference of the endangered tarantula, Brachypelma klaasi (Araneae: Theraphosidae) in Mexico. Biodiversity and Conservation, 9: 795810.

Yáñez, M., A. Locht \& R. Macías-Ordóñez. 1999. Courtship and mating behavior of Brachypelma klaasi (Araneae: Theraphosidae). Journal of Arachnology, 27: 165-170. 